\title{
Influence of waterlogging stress and benzyladenine application on tomato grafted to eggplant
}

\author{
Mary Ann Jully B. Regis' and Misael T. Diputado, Jr. ${ }^{2}$ \\ 'Palawan State University, Puerto Princesa, Palawan,Philippines; and \\ ${ }^{2}$ Department of Horticulture, Visayas State University (formerly Leyte State \\ University), Baybay City, Leyte, Philippines 6521-A
}

\section{ABSTRACT}

Under waterlogged conditions, the non-grafted tomato plants had significantly lower survival rate $(53 \%)$ compared to the grafted plants ( $100 \%$ survival rate). Under waterlogged conditions both the grafted and non-grafted plants had high leaf stomatal resistance, low transpiration rate and high stress rating, compared to those under nonwaterlogged conditions. However, one week after resumption of aerobic soil conditions, both stomatal resistance and transpiration as well as stress rating returned to normal in grafted plants while the non-grafted plants continue do show high stomatal resistance, low transpiration rates and high stress rating. The morphological changes associated with stress in the plant regardless of treatments were cupping, drooping and eventual wilting of leaves. Due to severe stress under waterlogged conditions, the non-grafted plants had significantly lower yield which was just about $41 \%$ of that in grafted plants. The grafted, non-waterlogged plants had comparable yield with the non-grafted, nonwaterlogged plants. Application of benzyladenine was not effective in alleviating waterlogging stress effects on both grafted and non-grafted tomato.

Keywords: grafted tomato, eggplant, waterlogging, benzyladenine, stomatal resistance, transpiration

Correspondence: M. T. Diputado Jr. Address: Department of Horticulture. Visayas State University, Baybay City, Leyte, 6521-A. Philippines. Email: mtdiputado.Iralyahoo.con. Tel. No. (053) 563-7051

DOI: $10.32945 /$ atr2927.2007 


\section{INTRODUCTION}

Tomato (Lycopersicon esculentum Mill) is one of the major vegetables grown in the Philippines. Consumption of this crop by Filipinos continues to increase due to its wide variety of uses and nutritional value. However, its production has been very limited and costly due to some constraints. These constraints include unfavorable environmental factors like high night temperature and flooded soils. Generally, flooding and waterlogging in lowland area could not be avoided especially in provinces like Leyte with Type IV rainfall pattern characterized by more or less even distribution of rainfall throughout the year. Waterlogging causes much damage to tomatoes during rainy season in the tropics. It can cause rapid wilting and senescence and depressed yield of the crop.

AVRDC (1993) reported that flooding problems can be solved by grafting tomato plant to flooding-tolerant eggplant rootstock. However, there have been no detailed reports on the physiological and morphological response of grafted and non-grafted plants to waterlogging stress that could relate to the improvement of growth, survival and yield of grafted plants relative to nongrafted plants under waterlogged conditions. Moreover, choosing the right variety of eggplant rootstock that can tolerate waterlogging stress is important.

The cause of early leaf senescence of a plant due to soil flooding could be due to hormonal imbalance in the plant's system. Jackson (1990) found that when the plant roots were subjected to waterlogging stress, slow shoot growth and leaf senescence were enhanced and substantial decrease in the concentration of cytokinin was observed. Benzyladenine (BA) is a synthetic purine cytokinin which has been shown to effectively delay senescence in soybean (Nooden et al., 1979). This hormone may thus have some practical application for the reduction of waterlogging damage on tomato.

This study was conducted to determine the morphological, physiological, growth and yield response of tomato (var. Diamante) grafted to eggplant (var. Mestiza) as well as that of non-grafted ones to simulated waterlogging and BA application. 


\section{MATERIALS AND METHODS}

\section{Raising of seedlings}

\section{Rootstock seedlings}

The eggplant variety used as rootstock was Mestiza, a variety known to be hardy and resistant to bacterial wilt, fruit borer and phomopsis. No report has yet been made on the physiological response of this eggplant variety under waterlogged condition. Seedlings were grown in individual pots one week before planting the tomato.

\section{Scion seedlings}

The tomato variety used as scion was Diamante. This variety is known to have some off-season adaptation to Philippine lowland conditions and with intermediate plant vigor. It is a non-determinate type variety and its first harvest can be made 37 days after transplanting. Its fruits are high round, with medium strong ribbing and a flat blossom end (BPI, 2005). Seedlings of this variety were raised using modified cellular method.

\section{Grafting and managing of seedlings}

The procedure of grafting followed that of Black et al. (2003) with some modifications. Seedlings were grafted after 2 to 3 true leaves were developed. Eggplant rootstock was cut above the cotyledons at a $30^{\circ}$ angle. On the other hand, the tomato stem (scion) was cut at a $30^{\circ}$ angle slightly above the cotyledons.

The cut portions of the scion and stock were joined, and then wrapped tightly with a $1.5 \mathrm{~cm} \times 1.5 \mathrm{~cm}$ tin foil. The tin foil was left attached on the seedling until it naturally loosened and fell off.

The grafted seedlings were moved immediatley into a shaded chamber with plastic cover. A shallow layer of water was kept on the polyethelene floor liner to maintain high humidity $(>85 \% \mathrm{RH})$. The seedling trays were placed on elevated wood blocks to support the plants above the waterline. 
Four to five days after grafting, the hardening process was imposed. The water from the floor pan was drained out. The chamber 's plastic cover door was opened. These conditions were maintained for two to three days. The grafted plants were moved out of the chamber and placed inside the screen house. Nine days after grafting, a foliar application of $0.3-0.4 \%$ urea was applied. The plants were held in the screenhouse for seven days for further development and hardening.

\section{Experimental design and treatments}

A three-factor factorial experiment in Randomized Complete Block Design (RCBD) was used in the study. The treatments were replicated three times with 8 plants per treatment. Factor A was grafting $\left(T_{1}\right.$ - non-grafted tomato plant; $T_{2}$ - grafted tomato plant). Factor $B$ was soil condition $\left(F_{1}-\right.$ not waterlogged; $F_{2}$ - waterlogged for four days). Factor $C$ was $B A$ application $\left(B_{1}\right.$ - without $B A$ application; $B_{2}$ - with $B A$ applied before flooding; $B_{3}$ - with $\mathrm{BA}$ applied before and during flooding).

\section{Transplanting, BA application, flooding and field management practices}

Seedlings were transplanted in polybags $(9 \mathrm{~cm} \times 9 \mathrm{~cm} \times 16 \mathrm{~cm})$ filled with $2: 1: 1$, v/v ratio of garden soil, compost and rice hull which were arranged inside a rain shelter with UV-stabilized plastic as cover.

BA solution was sprayed to the aerial parts of the plant at a concentration of $50 \mathrm{mg} / \mathrm{L}$ containing $0.01 \%$ Tween 80 .

Simulated waterlogging was done. Potted tomato plants were subjected to waterlogging 22 days after transplanting. This was done by submerging each pot in a plastic container filled with water, ensuring that the soil is saturated with water.

Each plant was applied with $10 \mathrm{~g}$ complete fertilizer (14-14-14) at planting, and 10 grams urea (46-0-0) plus $5 \mathrm{~g}$ muriate of potash (0-0-60) 30 days after transplanting and two weeks later. Foliar applicaton of calcium nitrate $\left(\mathrm{CaNO}_{3}\right)$ at $10 \mathrm{~g} / \mathrm{L}$ was done when blossom-end-rot was observed in some fruits.

The grafted plants were staked 2-3 weeks after transplanting. Water was done regularly to keep the soil sufficiently moist. The plants were monitored 
closely for pests. The use of hot pepper-soap spray was sufficient in minimizing the infestation of fruit borer (Helicoverpa armigera), leaf cutters (Agrotis epsilon), and leaf miners (Liriomyza munda).

The fruits were harvested at the mature-green stage. Harvesting by hand was done once a week until the last harvest. Fruits were then sorted as marketable and non-marketable.

Aside from horticultural and yield data, some physiological parameters including stress rating, stomatal resistance and transpiration rate were gathered. Stress rating was based on the morphological changes as well as degree of wilting of the plants using the criteria used by Diputado and Del Rosario (1985). Mid-day leaf stomatal resistance and transpiration rate were taken using LI1600 steady state porometer just before waterlogging, one hour after 4-day waterlogging, and one week after waterlogging imposition.

\section{RESULTS AND DISCUSSION}

\section{Plant height, number of leaves and days to maturity}

At flowering stage, grafted plants were significantly shorter than the nongrafted ones (Table 1). This may be because the rootstock was morphologically slow growing compared to the scion so that plant height as a whole was affected. Hartmann et al. (1997) maintained that size control is one of the most significant rootstock effects. Plant height was also significanlty influenced by waterlogging treatment but not by benzyladenine application. It was observed that during flooding the plants wilted and a week later, their growth became slower because some of their shoot tips have completely wilted. Hunt (1951) as cited by Kozlowski (1997), reported that flooding inhibits shoot growth. Furthermore, flooding critically affects internode formation in plants.

On the 27th and 41st day after transplanting, the number of leaves was significantly reduced in waterlogged, non-grafted plants (Table 2). This was due to wilting of the leaves with the shoot tips being primarily and severely affected. Eventually, the lower leaves senesced and fell off. Kozlowski $e t$ al. (1997) stated that flooding adversely affects shoot growth of many plants by suppressing leaf formation and expansion of leaves and internodes, causing premature leaf senescence and abscission, and shoot die back. The leaves of grafted tomatoes recovered earlier compared to the non-grafted tomato plants. 
Table 1. Plant height, number of leaves and number of days from transplanting to maturity of tomato plants as influenced by grafting, waterlogging and benzyladenine application

\begin{tabular}{|c|c|c|c|}
\hline Treatments & $\begin{array}{l}\text { Plant height }(\mathrm{cm}) \\
55 \text { days after } \\
\text { transplanting }\end{array}$ & $\begin{array}{l}\text { No. of leaves } \\
55 \text { days after } \\
\text { transplanting }\end{array}$ & $\begin{array}{l}\text { Number of } \\
\text { days from } \\
\text { transplanting } \\
\text { to maturity }\end{array}$ \\
\hline \multicolumn{4}{|l|}{ Grafting treatment } \\
\hline non-grafted & $95.58 \mathrm{a}$ & 19.42 & 55.79 \\
\hline grafted & $88.58 b$ & 19.70 & 53.63 \\
\hline \multicolumn{4}{|l|}{ Waterlogging treatment } \\
\hline not waterlogged & $96.13 \mathrm{a}$ & 20.42 & 52.25 \\
\hline waterlogged & $88.04 b$ & 18.13 & 57.17 \\
\hline \multicolumn{4}{|l|}{ BA application } \\
\hline w/o BA & 93.78 & 20.62 & 53.20 \\
\hline w/BA (applied 2 DBW) & 93.21 & 19.52 & 56.27 \\
\hline $\begin{array}{l}\text { w/ BA (applied 2 DBW } \\
\text { and during }\end{array}$ & & & \\
\hline waterlogging) & 89.26 & 18.55 & 54.66 \\
\hline CV(\%) & 5.05 & 10.73 & 25.21 \\
\hline
\end{tabular}

Table 2. Interaction effects of grafting, waterlogging and time of BA application on percent survival of tomato plants

\begin{tabular}{|c|c|c|c|}
\hline \multirow{2}{*}{$\begin{array}{l}\text { Grafting/ } \\
\text { Waterlogging } \\
\text { Treatments }\end{array}$} & \multicolumn{3}{|c|}{ Percent Survival } \\
\hline & Without BA & $\begin{array}{l}\text { With BA applied } 2 \\
\text { days before } \\
\text { waterlogging }\end{array}$ & $\begin{array}{l}\text { With BA applied } 2 \\
\text { days before and } \\
\text { during waterlogging }\end{array}$ \\
\hline \multirow{3}{*}{$\begin{array}{l}\text { Non-grafted } \\
\text { non-waterlogged } \\
\text { waterlogged }\end{array}$} & & & \\
\hline & $100.00 \mathrm{a}$ & $100.00 \mathrm{a}$ & $100.00 \mathrm{a}$ \\
\hline & $53.33 \mathrm{~b}$ & $41.47 \mathrm{~b}$ & $8.33 \mathrm{c}$ \\
\hline \multicolumn{4}{|l|}{ Grafted } \\
\hline non-waterlogged & $100.00 \mathrm{a}$ & $100.00 \mathrm{a}$ & $100.00 \mathrm{a}$ \\
\hline waterlogged & $100.00 \mathrm{a}$ & $100.00 \mathrm{a}$ & $100.00 \mathrm{a}$ \\
\hline
\end{tabular}

All means followed by a common letter are not significanlty different from each other (DMRT, $5 \%$ level). 
It took only a few days for the former to recover while the latter took at least two weeks. Some even failed to recover and just completely wilted. There was no significant difference in the number of leaves that developed between grafted and non-grafted tomatoes despite the shorter stature of the former plants.

Regardless of other treatments, the non-waterlogged plants matured approximatley 5 days ahead of the waterlogged plants (Table 1), although the difference was not significant. Lopez and del Rosario (1983) stressed that soil inundation alters the reproductive growth of plants, often inhibiting anthesis and fruit set. They observed that tomato plants were sensitive to waterlogging stress during their reproductive stage. Between grafted and non-grafted plants, there was also no significant difference in the number of days to first harvest despite the fact that grafted plants had to undergo a period of healing of their graft union.

\section{Percent plant survival}

Table 2 shows that growing non-grafted plants under simulated waterlogging condition drastically reduced percent plant survival. The treatment, however, did not affect plant survival of grafted plants which means that grafted plants were able to cope with the waterlogging stress. Clearly, the mechanism of tolerance of eggplant rootstock to waterlogged condition need to be studied further. Results also show that application of BAdid not improve survival of waterlogged plants and even caused more deaths in waterlogged, non-grafted plants,particularly when applied twice i.e. 2 days before and 2 days after start of waterlogging. The concentration of the chemical may have been too high to reduce the impact of flooding stress on the plant.

\section{Leaf stomatal resistance and transpiration rate}

Before waterlogging was imposed, leaf stomatal resistance of grafted and non-grafted plants were $2.70 \mathrm{~s} \mathrm{~cm}^{-1}$ and $2.75 \mathrm{~s} \mathrm{~cm}^{-1}$, respectively. Generally, plants have normal stomatal resistance of $2 \mathrm{~s} \mathrm{~cm}^{-1}$ to $3 \mathrm{~s} \mathrm{~cm}^{-1}$ (Lin et al., 2005). This means that the plant, before flooding was imposed, was physiologically normal as far as stomatal resistance is concerned. On the other hand, transpiration rate in both grafted and non-grafted plants were also comparable at $10.015 \mu \mathrm{g} \mathrm{cm}^{2} \mathrm{~s}^{-1}$ and $10.054 \mu \mathrm{g} \mathrm{cm}^{2} \mathrm{~s}^{-1}$.

One hour after 4 days of flooding, both grafted and non-grafted tomato 


\section{Leaf stomatal resistance $\left(\mathrm{s} \mathrm{cm}^{-1}\right)$}

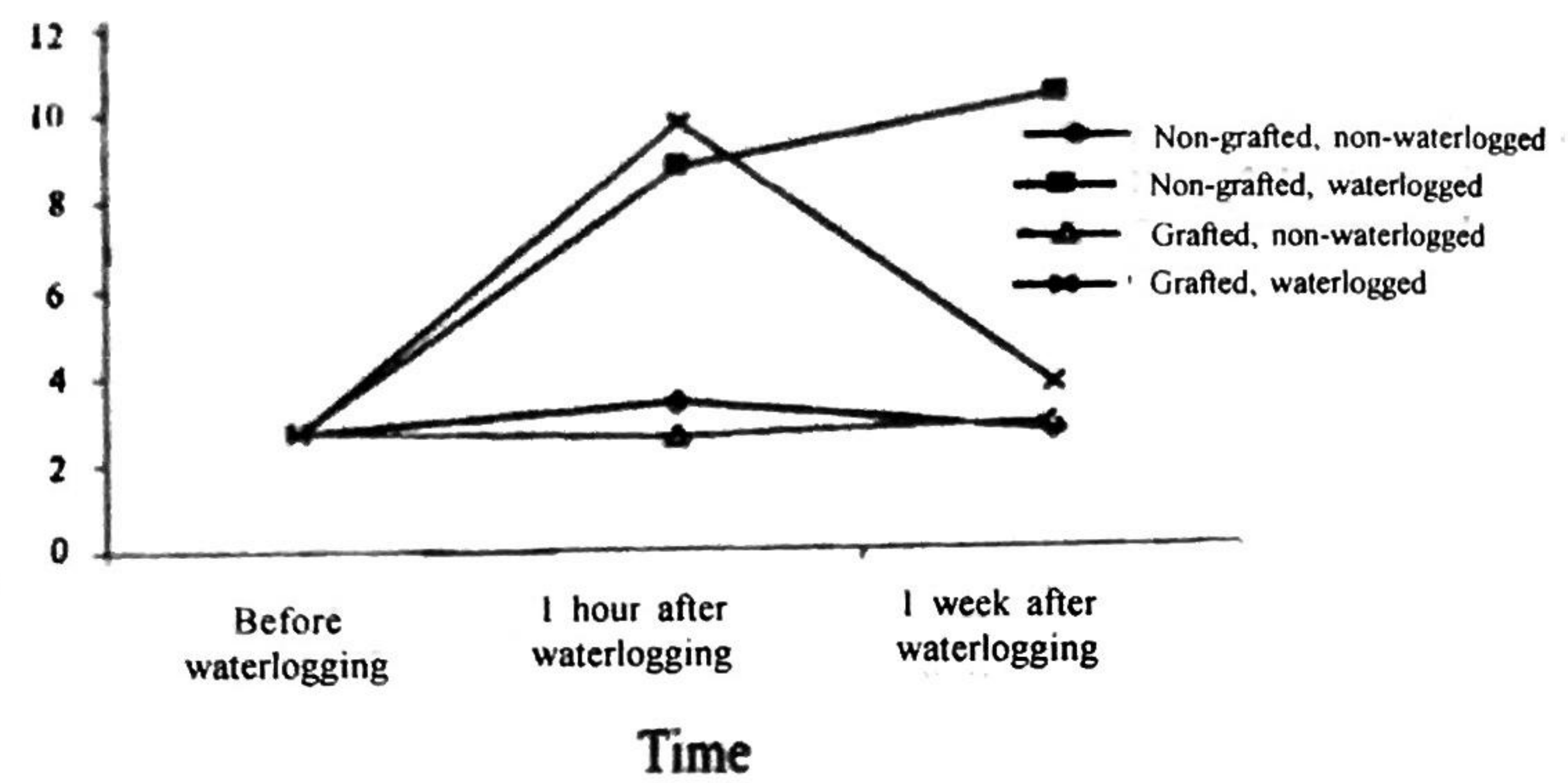

Figure 1. Leaf stomatal resistance (LSR) of tomato as influenced by grafting waterlogging and benzyladenine application

Transspiration rate $\left(\mu \mathrm{g} \mathrm{cm}^{-2} \mathrm{~s}^{-1}\right)$

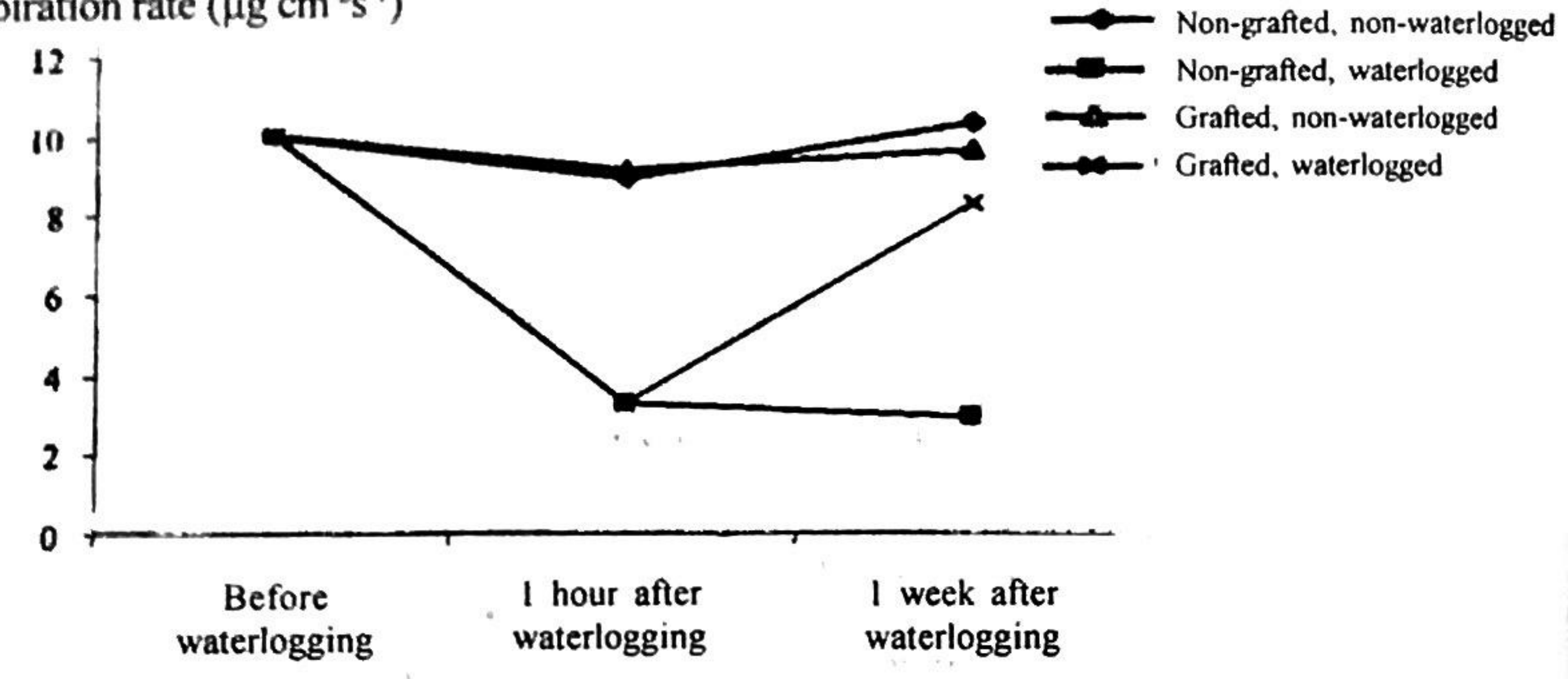

Time

Figure 2. Transpiration rate of tomato as influenced by grafting, waterlogging and benzyladenine application 
plants showed a three-fold increase in stomatal resistance (Fig. 1) and about $40 \%$ reduction in transpiration rate (Fig. 2), compared to the control plants. Both parameters did not significantly differ between the grafted and non-grafted plants. One week after imposition of waterlogging, the stomatal resistance of grafted plants returned to normal level while that of the non-grafted plants remained high (Fig. 1). The same was true to transpiration rate, which returned to normal in grafted plants and remained low in the non-grafted plants after stress imposition. Severe wilting was noticed in $80 \%$ of non-grafted plants, whereas, in grafted plants only $20 \%$ was observed to manifest wilting. Bradford and Hsiao (1982) reported that transpiration in tomato was reduced by $30 \%$ to $40 \%$ after 24 hours of soil flooding. In this study, most of the non-grafted plants did not recover because the stomatal resistance remained high and the transpiration rate low, which eventually caused permanent wilting to set in. Their stomates may have been permanently damaged after the stress and affected their photosynthetic potential. Kozlowski (1997) reported that soil inundation induces multiple physiological abnormalities in plants. Photosynthesis and transport of carbohydrates are inhibited, and absorption of macronutrients by plants under flooded soil is affected because of root mortality. Interestingly, the fast recovery of grafted plants from stress could be due to the transient wilting of their leaves in response to stress which prevents further water loss through transpiration, and stability of the roots of the rootstock which enabled them to continue normal absorption of water as soon as stress was relieved. This adaptive mechanism is advantageous during the hot-wet-season and for off-season production of tomatoes.

\section{Stress rating and morphological changes}

Table 3 shows that under flooded conditions, the non-grafted plants were stressed more severely compared to the grafted plants. Figure 3 shows that application of benzyladenine did not help to alleviate stress condition in waterlogged plants but even increased it particularly when applied twice i.e. before and during flooding.

In non-grafted, waterlogged plants, the leaves were reoriented to a near vertical position with more than $1 / 2$ to $3 / 4$ of foliage showing wilting and with most of the leaves completely wilted or dried. Senescence and abscission of the basal leaves were also observed. On the other hand, the waterlogged, grafted plants showed mild stress only, which was characterized by drooping and yellowing of basal leaves. One week after resumption of normal soil 
Table 3. Interaction effects of grafting and waterlogging on stress rating of tomato plants

\begin{tabular}{llll}
\hline $\begin{array}{l}\text { Grafting/ } \\
\text { waterlogging } \\
\text { treatments }\end{array}$ & $\begin{array}{l}\text { Before } \\
\text { waterlogging }\end{array}$ & $\begin{array}{l}\text { One hour after } \\
\text { waterlogging }\end{array}$ & $\begin{array}{l}\text { One week after } \\
\text { waterlogging }\end{array}$ \\
\hline $\begin{array}{l}\text { Non-grafted } \\
\text { non-waterlogged }\end{array}$ & 0.00 & $0.00 \mathrm{c}$ & $0.00 \mathrm{~b}$ \\
waterlogged & - & $4.61 \mathrm{a}$ & $4.08 \mathrm{a}$ \\
Grafted & & $0.00 \mathrm{c}$ & $0.00 \mathrm{~b}$ \\
$\quad$ non-waterlogged & 0.00 & $2.59 \mathrm{~b}$ & $0.43 \mathrm{~b}$ \\
$\quad$ waterlogged & - & & \\
\hline
\end{tabular}

Means followed by a common letter are not significantly different (DMRT, $5 \%$ level) Stress rating:

0 - no stress

1 - slight cupping and/or drooping of leaves

2 - cupping and/or drooping of leaves accompanied by yellowing of basal leaves and drying of tips of leaves

3 - reorientation of leaves to a near vertical orientation and wilting of not more than $1 / 2$ of the leaflets; senescence and abscission of basal leaves

4 - reorientation of leaves to a near verticla position and wilting of more than $1 / 2$ but not more than $3 / 4$ of foliage; most leaves senescing

5 - leaves of most plants are completely wilted or dried

conditions, the non-grafted plants were still stressed while the grafted plants recovered. Thus, grafted plants showed the ability to overcome stress earlier before permanent injury occurs by some mechanisms which need to be studied further, as pointed out earlier.

\section{Yield and yield components}

Table 4 shows that the number and weight of marketable and nonmarketable fruits as well as the total fruit weight per plant were significantly reduced by half in waterlogged plants compared to non-waterlogged plants. Moreover, the dry matter yield was observed to be significantly lower in waterlogged than in non-waterlogged plants.

The number of fruits as well as the average fruit yield of tomato whether marketable or not were higher in grafted plants than in non-grafted. Under waterlogged conditions, the grafted plants had considerably higher yield 

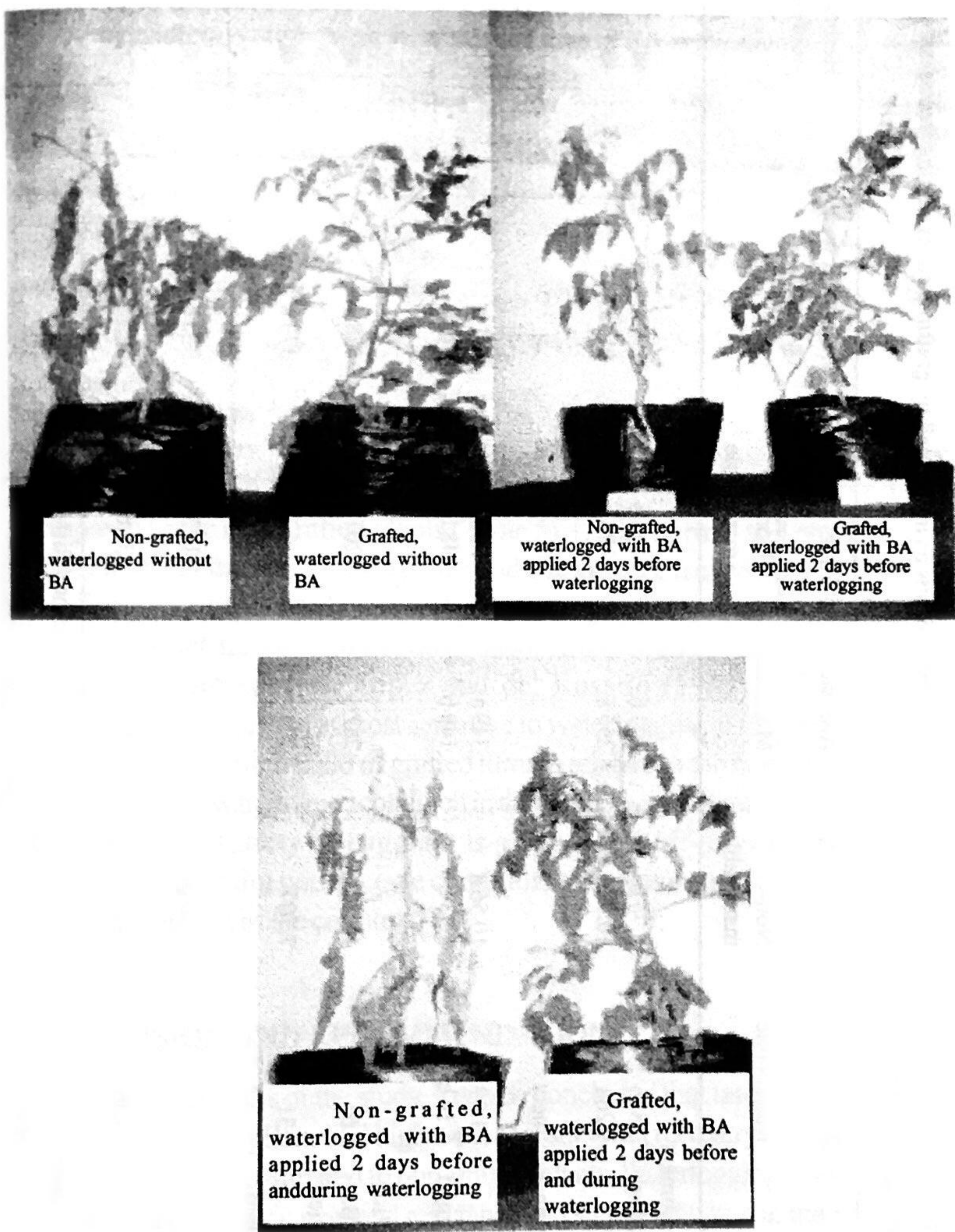

Figure 3. Effects of grafting and benzyladenine application on manifestation of stress in tomato plants under waterlogged conditions 


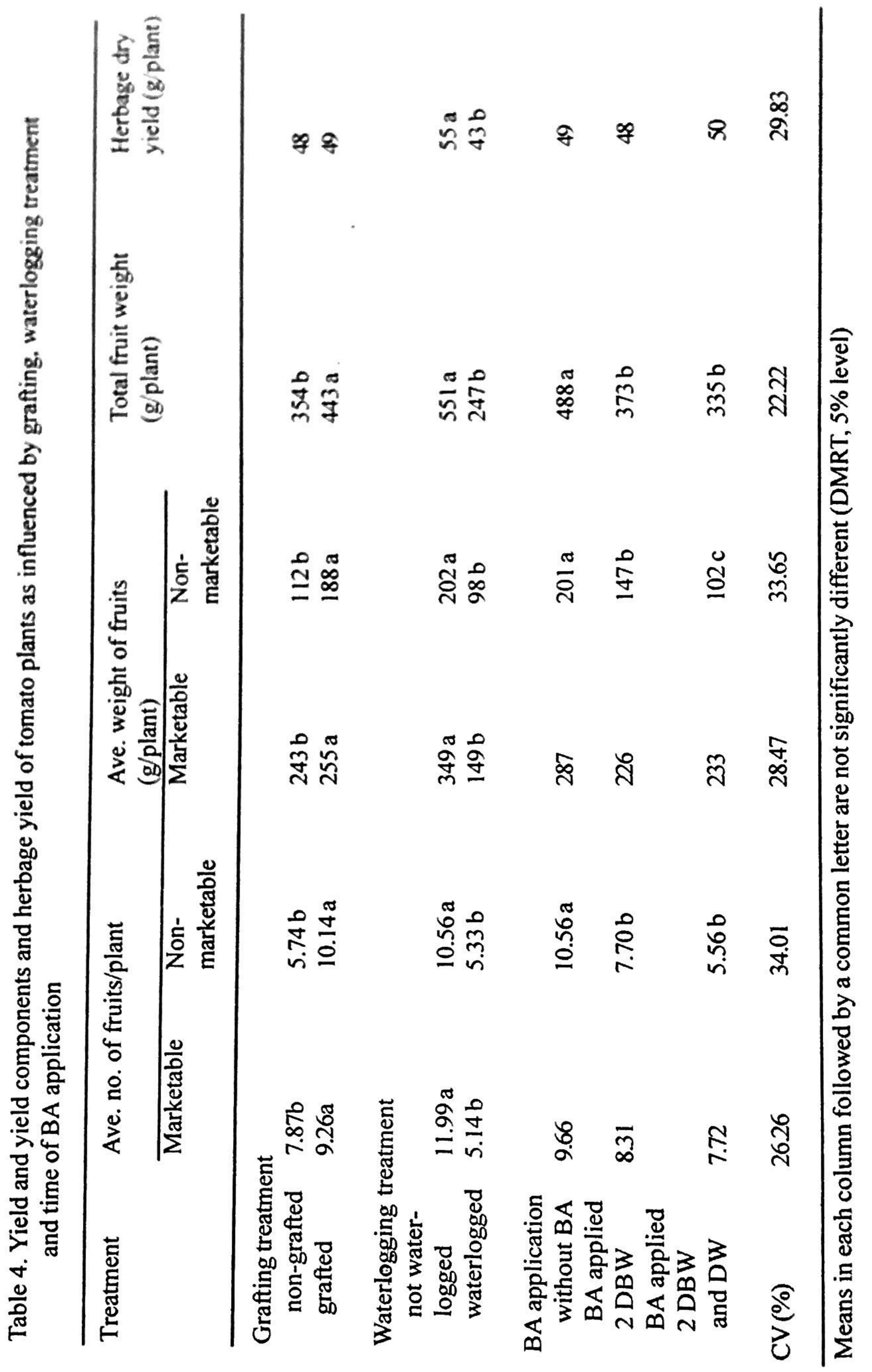


Table 5. Interaction of grafting and waterlogging treatments on fruit and herbage dry matter yield of tomato

\begin{tabular}{lllll}
\hline $\begin{array}{l}\text { Grafting/ } \\
\text { waterlogging } \\
\text { Treatents }\end{array}$ & \multicolumn{2}{c}{ Fruit Yield (g/plant) } & Total & $\begin{array}{l}\text { Herbage } \\
\text { Dry yield } \\
\text { (g/plant) }\end{array}$ \\
\hline $\begin{array}{lllll}\text { Non-grafted } \\
\text { non-water- }\end{array}$ & & Non-marketable & & \\
logged & $398 \mathrm{a}$ & $183 \mathrm{a}$ & $581 \mathrm{a}$ & $30.41 \mathrm{a}$ \\
waterlogged & $87 \mathrm{c}$ & $40 \mathrm{~b}$ & $127 \mathrm{c}$ & $17.78 \mathrm{~b}$ \\
& & & & \\
Grafted & & & & \\
$\begin{array}{l}\text { Non-water- } \\
\text { logged }\end{array}$ & $300 \mathrm{ab}$ & $221 \mathrm{a}$ & $521 \mathrm{a}$ & $24.68 \mathrm{ab}$ \\
waterlogged & $209 \mathrm{~b}$ & $156 \mathrm{a}$ & $365 \mathrm{~b}$ & $25.11 \mathrm{ab}$ \\
\hline
\end{tabular}

compared to the non-grafted plants (Table 5). Under normal soil conditions, the grafted and the non-grafted plants had comparable fruit yields.

Results of this study support the findings of other authors that soil inundation often inhibits flower bud initiation, fruit set, and fruit enlargement in flood-intolerant species. Lopez and del Rosario (1983), for instance, emphasized that tomato is most sensitive to waterlogging at flowering stage. The considerably high yield of grafted tomato relative to the non-grafted ones under simulated waterlogged condition in this study suggests that grafting tomato to the Mestiza variety of eggplant is a very good off-season production technique especially under Leyte conditions where the amount of rainfall is one of the highest in the country.

\section{CONCLUSION AND RECOMMENDATION}

From the results of the study, it can be concluded that under waterlogged conditions, grafted plants had higher percent survival, recovery rating and fruit and herbage yields compared to non-grafted plants. Waterlogging stress caused a significant increase in stomatal resistance and significant drop in transpiration rate in both grafted and non-grafted plarits. These physiological parameters, however, returned to normal one week after stress imposition in grafted plants but not in non-grafted plants. Benzyladenine application did not improve survival and, growth and yield of tomato plants subjected to waterlogging.

Grafting tomato plants into eggplant rootstock (variety Mestiza) is thus 
recommended to maintain high yield level of tomato even under waterlogged conditions. There is, however, a need to study further the influence of watcrlogging at different stages of plant growth. Also the influence of lower concentrations of BA on the performance of tomato under waterlogged conditions should be assessed. Finally, the performance of grafted tomato plants under actual field conditions , particularly, during rainy days should be evaluated.

\section{LITERATURE CITED}

AVRDC. 1993. Progress Report. Asian Vegetable Research and Development Center, Shanhua, Tainan, Taiwan. (ROC).

BLACK, L.L., D. L. WU, J. F. WANG, T. KALB, D. ABBASS and J. H. CHEN. 2003. Grafting tomatoes for hot-wet season. AVRDC International Cooperator's Guide. http://www.avrdc.org.

BPI. 2005. Crop Varieties. Bureau of Plant Industry. Plant Variety Gazette. Vol.1, Issue 1.

BRADFORD, K. J. and T.L. HSIAO. 1982. Stomatal behavior and water relations of waterlogged tomato plants. Plant. Physiol. 70:1508-1513.

DIPUTADO, M. T. and D. A. DEL ROSARIO. 1985. Response of cowpea (Vigna sinesis L.) to moisture stress and seed pretreatment.Phil J. Crop Sci. 10(2):51-56.

HARTMANN, H. T., D. E. KESTER, F. T. DAVIES, JR. and R. L. GENEVE. 1997. Plant Propagation: Principles and Practices. 6th edition. Prentice Hall Int. Inc., USA. 770p.

JACKSON, M. B. 1990. Hormones and developmental changes inplant subjected to submergence or soil waterlogging. Aquatic Bot., 38:49-72.

KOZLOWSKI, T. T. 1997. Response of woody plants to flooding and salinity. http:// www.heronpublishing.com/tp/monograph/kozlowski.pdf

LIN, S. H., Y. X. HUANG R. Z. HAN and Y. YAO. 2005. Using stomatal resistance index of plants to evaluate the quality of atmospheric environment in Fuzhou. Journal of Integrative Plant Biology (Acta Botanica Sinica).

LOPEZ, M. V. and D. A. DEL ROSARIO. 1983. Performance of tomatoes (Lypersicon esculentum) under waterlogged conditions. Phil. J. Crop. Sci. 8:75-80.

NOODEN, L. D., G. M. KAHANAK and Y. OKATAN. 1979. Prevention of monocarpic senescence in soybeans with auxin and cytokinin: An antidote for self-destrcution. Science 206:841. 